\title{
SOME OBSERVATIONS ON THE TRANSPORT OF FOOD IN THE ALIMENTARY CANAL OF THE RAT
}

\author{
Lauri Paloheimo, Aarne Mäkelä and Maija-Lissa Salo
}

Department of Animal Husbandry, University of Helsinki

Received November 2nd, 1953

\section{Definition of the subject and review of earlier investigations}

Some investigations concerning the transport of food in the alimentary canal of the rat have previously been made in this laboratory (PALoheimo, 9, p. 380-382). Here we have studied 1) the effect of the degree of fullness of the stomach upon its rate of emptying, and 2) the rate of passage of the food in the empty small intestine. Apart from the Palohermo's paper (1.c.) we have found only a few publications that deal directly with our present subject. Therefore we shall chiefly refer to papers concerned with the transport of food in man and in animals with a simple stomach other than the rat.

According to Scheunert and Trautman (11, p. 103) the emptying of the stomach in carnivores does not usually begin less than $1 / 2$ hour p.c. ${ }^{1}$ KRZYwaneK $(5$, p. 515), using the $\mathrm{x}$-ray method, observed that in puppies the discharge from the stomach began $30-60$ minutes p.c. The pups had received $10-50 \mathrm{~g}$. minced meat. The filling of the colon began about 4 hours p.c. and the small intestine was empty $7 \frac{1}{2}-10 \frac{1}{2}$ hours p.c. Magnus (7, p. 227) states that the emptying of the stomach may begin as early as 15 minutes p.c. Stickney et al. (13 p. 399-402) studied, by slaughter tests in dogs, the correlation between the length of the small intestine and the distance (from the pylorus) that an inert test meal traversed in 30 minutes. In dogs with a long small intestine the proportion traversed was $67 \%$ of the length of the small intestine, whereas in dogs with a short small intestine the corresponding figure was 56 .

In man RIEDER (10, p. 464-465), using the x-ray method, observed the contrast gruel in the duodenum immediately after the meal. Fifteen minutes after the test subject had finished a meal consisting of $250 \mathrm{~g}$. of gruel there was contrast material in the ileum, and the stomach was empty $31 / 4$ hours later. The jejunum was discharged 4 hours p.c., and the ileum 2 hours later. The experimental meal reached the

${ }^{1}$ p.c. $=$ post cenam $=$ after the meal 
caecum 3 hours p.c. Referring to several investigators ScHinz, BAENSCH and FRIEDL $(12$, p. 3097$)$ state that $1 \frac{1}{2}$ hours p.c. $10-75 \%$ of the food eaten had left the stomach. $1 \frac{1}{2}$ hours later the corresponding figure was $30-95$, and after a further $1 \frac{1}{2}$ hours (4 $1 / 2$ hours p.c.) it was $60-90$. Nothing is mentioned about the volume of the food portions nor about the method used. The above authors draw attention to some types of especially rapid movements of the small intestine which are distinguished from the general type of peristaltic movement. They call them Rollbewegung or Peristaltische Sturz. (ibid. p. 3261). Without indicating the volume of the portions, SwINEy and SPURrell (14, p. 43) state that meals that were poor in fat were emptied from the stomach in $2 \frac{1}{2}-3$ hours and those rich in fat in $6 \frac{1}{2}-7$ hours. Crider and Thomas (ref. Evans 3, p. 838) ${ }^{1}$ state that after large meals the emptying time of the stomach is longer in most subjects than after small meals. Doubling a small test meal may increase the time by 17 per cent, and trebling it may increase it by 38 per cent. BARCLAY describes at length the nature of the movements in the small intestine. He states (p. 166) that »throughout the intestinal tract peristalsis can be regarded not as the main factor but one of the main reserve mechanismus». He calls attention to the importance of the muscularis mucosae in the transport of food in the small intestine, and suggests that negative pressure may also play a part. In the terminal ileum waves of peristalsis are seen comparatively seldom, and the picture there is a very different one from the restlessness of the duodenum and jejunum. According to BARCLAY the first of the food is seen in the caecum $1 \frac{1}{2}-2$ hours p.c. BAyliss and Starling (ref. Evans, 3 p. 856 ) describe peristalsis as a wave moving slowly - generally at about $2 \mathrm{~cm}$. a minute — involving contraction of the gut above the food mass, and relaxation below it. According to Alvarez (ref. Evans, 3 p. 857), the peristaltic wave as described by BAyliss and STARLING, is abnormal, and in his opinion true peristalsis consists of a series of "rushes" traversing the whole length of the small intestine, travelling much more rapidly, 2 to $25 \mathrm{~cm}$. per second. Evans (1.c.) considers that probably both forms of peristalsis occur. Magnusson and Soveri (ref. Lönnerblad, 6 p. 12) found that air can pass through the small intestine in about 10 minutes. LönNERBLAD (6. p. 45), using the $x$-ray method, has examined the transit time of contrast gruel through the small intestine in 109 adults. The volume of the meal was $200 \mathrm{ml}$. The transit time was reckoned from the time when the test subject had drunk the contrast meal to the moment when the contrast gruel reached the caecum. In none of the test subjects was the transit time less than 30 minutes, and in only 5 cases was it less than 60 minutes. In the majority of cases it was over 2 hours, and in some cases over 5 hours.

In their slaughter tests, Ellenberger and Hofmeister (2, p. 295-296) noticed that in swine the emptying of the stomach started during the first hour p.c. when potatoes were fed. 2 hours p.c. $1 / 3$ of the meal had disappeared. When oats were fed, the rate of emptying was lower, The amounts of food given are not mentioned.

1 Evans refers to the Amer. J. Physiol. 1938, 123, 44, but we have not been able to find there the quotation in question. 
Out of $500 \mathrm{~g}$. of minced meat $23 \%$ disappeared from the stomach during the first hour p.c., $32 \%$ in the course of 3 hours, $50 \%$ in 5 hours, and $88 \%$ in 12 hours. Neimeier ( 8 p. $42-45$ ), in his x-ray experiments, fed swine with $400-500 \mathrm{~g}$. porridge which contained ein handvoll von Kartoffelflocken. During the first 1/2 hours the emptying of the stomach was especially vigorous. Even while the feeding was going on, the porridge reached the jejunum. NEIMEIER calls attention to the rush movements in the small intestine. $6-10$ hours p.c. the jejunum was empty. The filling of the colon began $2 \frac{1}{2}-3$ hours p.c.

Hagemeier (ref. Neimeier, p. 15) observed that in the duodenum of the goat the transport of food reaches a velocity of $25-30 \mathrm{~cm}$. in 3 seconds.

In Paloheimo's (1.c.) experiments, the rats, after 12 hours' fasting, received cakes which were baked from $3 \mathrm{~g}$. wheat flour and contained $\mathrm{Cr}_{2} \mathrm{O}_{3}$ as tracer. After this the animals ate dried rye bread ad libitum. The latter circumstance, as PALOHE Imo shows, had a delaying effect, especially on the transport of the last remnants of the test meal proper from the stomach to the duodenum. The rats were killed $1,2,4,6$ or 9 hours p.c. The amount of tracer still left in the ventriculum is seen in the table below.

\begin{tabular}{cc}
$\begin{array}{c}\text { Hours p.c. when } \\
\text { rat killed }\end{array}$ & $\begin{array}{c}\% \\
\text { tracer still eft in } \\
\text { stomach }\end{array}$ \\
\hline 1 & 82,3 \\
1 & 76,5 \\
\hline 2 & 54,6 \\
2 & 57,4 \\
\hline 4 & 11,9 \\
4 & 21,3 \\
\hline 6 & 26,1 \\
\hline 9 & 15,9 \\
9 & traces
\end{tabular}

1 hour p.c. the caecum contained traces of $\mathrm{Cr}_{2} \mathrm{O}_{3}$, and 6 hours p.c. only traces of this marker were left in the small intestine. When in the test cakes there was a $50 \%$ substitution of egg white powder, the transport of the marked food was clearly delayed not only in the stomach but also in the small intestine.

Goodman et al. (4. p. 236-241) injected $0,5 \mathrm{ml}$. of an aqueous solution of Evans Blue dye with a soft rubber catheter into the empty stomach of rats, after which the animals were allowed food ad libitum. After 1 hour $50-74 \%$ of the dye was found in the stomach but none in the caecum. After 2 hours $6-30 \%$ was found in the caecum.

STICKNEY et al (13, p. 400-401) studied the rate of passage of an inert test meal in the small intestine of rats weighing between 152 and $370 \mathrm{~g}$. They found that the proportion traversed in 40 minutes was about $72,5 \%$ of the length of the small intestine, independent of the length of the intestine. 


\section{Rate of emptying of the rat stomach}

In the present investigation 33 rats were used. 19 of them were females and 14 males. The age of the females was about $6-7$ months, and of the males about 4 months. Notwithstanding the inferiority in age the males slightly exceeded the females in average weight, which was about $200 \mathrm{~g}$. In the behaviour of the two sexes there was no difference discernible in our experiments. The rats were yellow hoods of local breed.

For the experiments wheat bread was baked. The dough also contained milk, sugar, coco fat, yeast and common salt. The bread was fed dried.

The rats were kept without food for 18 hours before being given the experimental meal. They were allowed to eat different amounts of the experimental food and were killed 2 (17 rats) or 3 (16 rats) hours after the beginning of the meal. The amounts of dry matter eaten and of dry matter in the ventriculum were established. They are shown in table 1 .

Table 1 .

\begin{tabular}{|c|c|c|c|c|c|c|c|}
\hline \multirow[b]{2}{*}{$\begin{array}{l}\dot{0} \\
z \\
0 \\
0 \\
0 \\
0\end{array}$} & \multirow{2}{*}{ 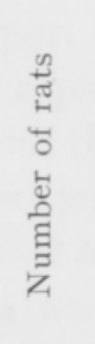 } & \multicolumn{2}{|c|}{$\begin{array}{l}\text { Dry matter } \\
\text { eaten }\end{array}$} & \multicolumn{2}{|c|}{$\begin{array}{l}\text { In stomach, } \\
\text { average }\end{array}$} & \multicolumn{2}{|c|}{$\begin{array}{l}\text { Grams of dry matter emptied } \\
\text { from stomach, average during }\end{array}$} \\
\hline & & $\begin{array}{l}\stackrel{\infty}{\Xi} \\
g \\
g\end{array}$ & 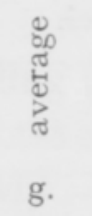 & $\begin{array}{c}\text { after } \\
2 \text { hours } \\
\text { g. }\end{array}$ & $\begin{array}{c}\text { after } \\
3 \text { hours } \\
\text { g. }\end{array}$ & $\begin{array}{l}\text { first } \\
2 \text { hours } \\
\text { g. }\end{array}$ & $\begin{array}{l}\text { 3rd } \\
\text { hour } \\
\text { g. }\end{array}$ \\
\hline I & $8+7$ & $2.61-2.87$ & 2.78 & $0.96 \pm 0.08$ & $0.31 \pm 0.07$ & 1.82 & $0.65 \pm 0.11$ \\
\hline II & $4+6$ & $5.39-6.26$ & 5.88 & $3.52 \pm 0.15$ & $2.59 \pm 0.15$ & 2.36 & $0.93 \pm 0.21$ \\
\hline III & $5+3$ & $6.62-8.26$ & 7.43 & $5.00 \pm 0.33$ & $4.32 \pm 0.50$ & 2.43 & $0.68 \pm 0.60$ \\
\hline
\end{tabular}

The average duration of the meal time in groups I, II and III was 14, 28, and 39 minutes respectively. As it is obvious that the emptying of the stomach began before the meal ended, the differences in the charge of the stomach cannot be as sharp as the differences in the amount of dry matter eaten. However, the amounts of dry matter emptied from the stomach during the first 2 hours seem to increase as the amount of the dry matter eaten increases (table 1).

In fig. 1 we have plotted the amounts of dry matter transferred from the stomach during the first 2 hours against the amounts of dry matter eaten. The regression is compatible with the equation $\mathrm{y}=0.12 \mathrm{x}+1.52$.

The following figures show that the animals which were killed 3 hours after the beginning of the meal ate on the average nearly the same amounts of dry matter as their group mates which were killed 1 hour later:

$\begin{array}{crcc} & & 2 \text { hours } & 3 \text { hours } \\ \text { Group } & \text { I } & 2.79 \mathrm{~g} . & 2.76 \mathrm{~g} . \\ \text { " } & \text { II } & 5.77 \mathrm{~g} . & 5.96 \mathrm{~g} . \\ \text { " } & \text { III } & 7.41 \mathrm{~g} . & 7.46 \mathrm{~g} .\end{array}$




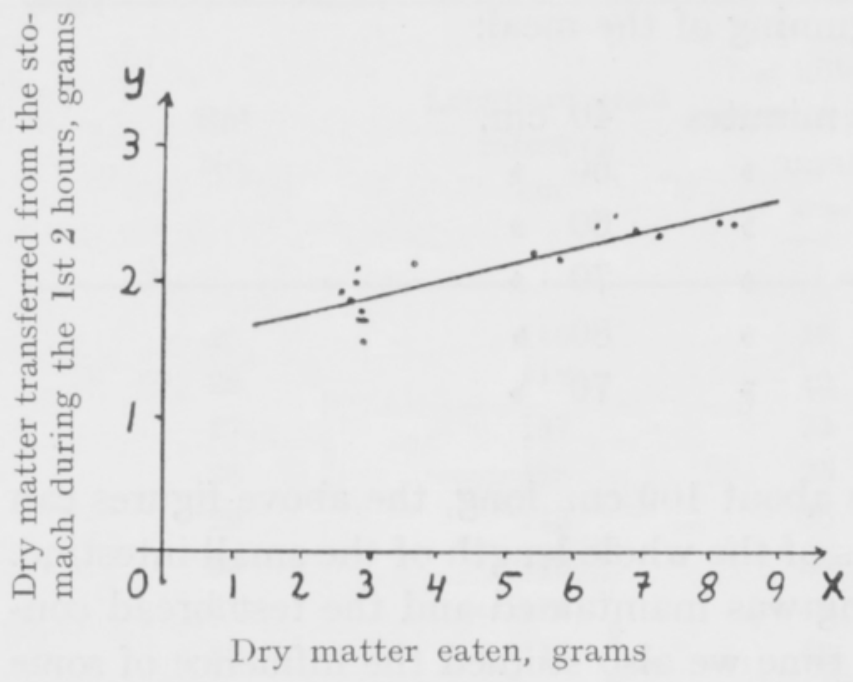

Figure 1.

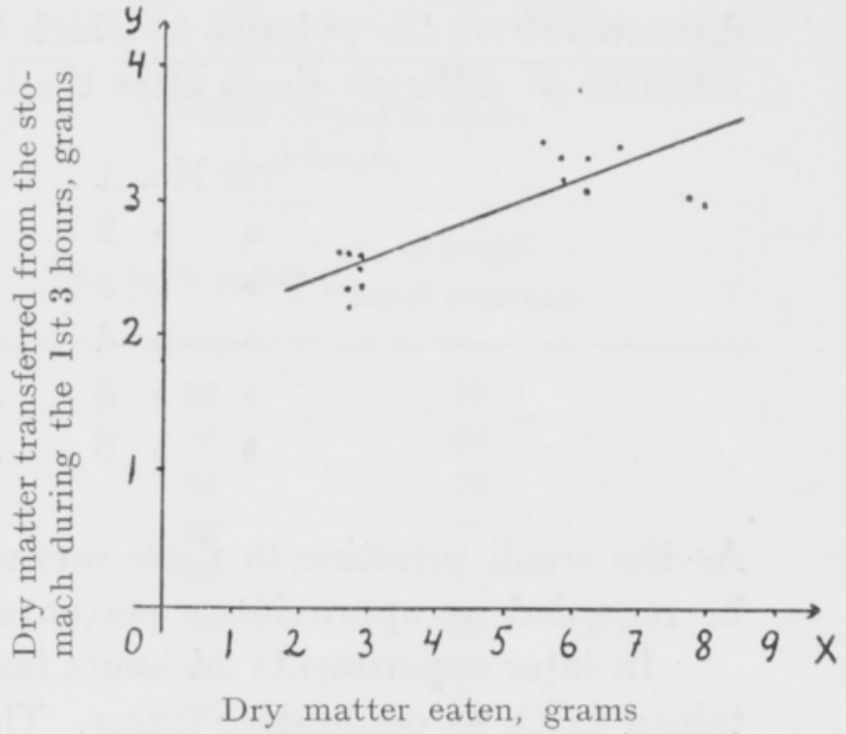

Figure 2.

This observation justifies the calculation of the amount of dry matter emptied from the stomach during the 3rd hour by subtracting in each group the average amount of dry matter in the stomach after 3 hours from the amount after 2 hours. The last column of table 1 shows the results of this calculation. If one compares these figures with the charge of the stomach at the beginning of the 3 rd hour, one notices that the last of them $(0,68)$ is unexpectedly low. This figure is rather uncertain, however, because only 3 of the animals of group III were killed after 3 hours.

From the figures in table 1 one can calculate the amounts of dry matter transferred from the stomach during the 3 hours after the beginning of the meal:

$\begin{array}{lrr}\text { Group } & \text { I } & 2.47 \mathrm{~g} . \\ " & \text { II } & 3.29 \mathrm{~g} . \\ " & \text { III } & 3.11 \mathrm{~g} .\end{array}$

In fig. 2 is seen the amounts of dry matter transferred from the stomach during the first 3 hours plotted against the amount of dry matter eaten. The regression is compatible with the equation $\mathrm{y}=0.19 \mathrm{x}+2.01$.

Of the total dry matter transport during the first 3 hours, only about $25 \%$ occurred during the 3 rd hour. The percentages in groups I, II and III were 26.5, 27.7 , and 21.7 respectively.

\section{Transport of food in the empty small intestine of the rat}

In the first experiments of this series, adult rats were permitted to fast for 17 hours. During the 24 hours before fasting they were fed with rutabagas only. Dried bread baked from whole kernel wheat meal was used as experimental food. The animals were killed 2, 5, 10 or 20 minutes after the beginning of the test meal, and the small intestine was examined immediately after. The procedure of killing the rat and taking out the intestine took about 2 minutes. The following figures show the 
distances (from the pylorus) at which the kernel membranes were found in the small intestine at different times after the beginning of the meal:

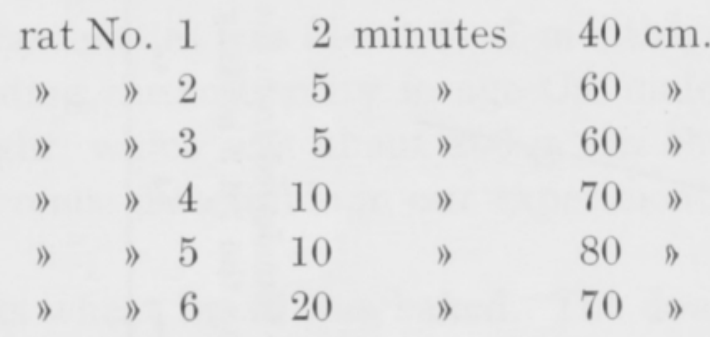

As the small intestine in these rats was about $100 \mathrm{~cm}$. long, the above figures can be regarded as approximate percentages of the whole length of the small intestine.

In later experiments 24 hours fasting was maintained and the test bread contained $\mathrm{Cr}_{2} \mathrm{O}_{3}$ as qualitative tracer. This time we also studied the influence of some variations in the test bread: Bread Nr. I was ordinary wheat bread, in Nr. II extracted soy meal was substituted for $10 \%$ of the wheat flour, in Nr. III vegetable oil was used in the same proportion. Nr. IV was not bread at all but beaten and baked egg white. These differences in the composition of food, however, seemed to have no

Table 2.

\begin{tabular}{|c|c|c|c|c|c|}
\hline \multirow{2}{*}{$\begin{array}{l}\text { Diet } \\
\text { No. }\end{array}$} & \multirow{2}{*}{$\begin{array}{l}\text { Rat } \\
\text { No. }\end{array}$} & \multirow{2}{*}{$\begin{array}{l}\text { Length of } \\
\text { small } \\
\text { intestine } \\
\quad \mathrm{cm} .\end{array}$} & \multirow{2}{*}{$\begin{array}{l}\text { Rat killed } \mathrm{X} \\
\text { minutes after } \\
\text { beginning } \\
\text { the meal } \\
\mathrm{x}=\end{array}$} & \multicolumn{2}{|c|}{$\begin{array}{l}\text { Advance of food in } \\
\text { small intestine }\end{array}$} \\
\hline & & & & $\begin{array}{l}\mathrm{cm} . \text { from } \\
\text { pylorus }\end{array}$ & $\begin{array}{l}\% \text { of length of } \\
\text { small intestine }\end{array}$ \\
\hline \multirow{4}{*}{ I } & 7 & 100 & 5 & 65 & 65 \\
\hline & 8 & 100 & 7 & 60 & 60 \\
\hline & 9 & 107 & 10 & 70 & 65 \\
\hline & 10 & 108 & 15 & 81 & 75 \\
\hline \multirow{4}{*}{ II } & 11 & 95 & 5 & 50 & 53 \\
\hline & 12 & 101 & 7 & 70 & 69 \\
\hline & 13 & 115 & 10 & 90 & 78 \\
\hline & 14 & 104 & 15 & 80 & 77 \\
\hline \multirow{5}{*}{ III } & 15 & 107 & 5 & 64 & 60 \\
\hline & 16 & 113 & 7 & 70 & 62 \\
\hline & 17 & 113 & 10 & 78 & 69 \\
\hline & 18 & 112 & 15 & 85 & 76 \\
\hline & 19 & 109 & 20 & 62 & 57 \\
\hline \multirow{5}{*}{ IV } & 20 & 112 & 5 & 65 & 58 \\
\hline & 21 & 107 & 7 & 62 & 50 \\
\hline & 22 & 109 & 10 & 78 & 72 \\
\hline & 23 & 106 & 15 & 81 & 76 \\
\hline & 24 & 110 & 20 & 80 & 73 \\
\hline
\end{tabular}


Table 3 .

\begin{tabular}{|c|c|c|c|c|}
\hline \multirow{2}{*}{$\begin{array}{l}\text { Rat } \\
\text { No. }\end{array}$} & \multirow{2}{*}{$\begin{array}{l}\text { Length of small } \\
\text { intestine } \\
\mathrm{cm} .\end{array}$} & \multirow{2}{*}{$\begin{array}{c}\text { Rat killed } \mathrm{x} \\
\text { minutes after } \\
\text { meal } \\
\mathrm{x}=\end{array}$} & \multicolumn{2}{|c|}{$\begin{array}{l}\text { Advance of food in small } \\
\text { intestine }\end{array}$} \\
\hline & & & cm. from pylorus & $\begin{array}{l}\% \text { of length of } \\
\text { small intestine }\end{array}$ \\
\hline 25 & 110 & 15 & 82 & 75 \\
\hline 26 & 117 & 15 & 80 & 68 \\
\hline 27 & 107 & 25 & 84 & 79 \\
\hline 28 & 108 & 25 & 83 & 77 \\
\hline 29 & 119 & 35 & 85 & 71 \\
\hline 30 & 113 & 35 & 94 & 83 \\
\hline 31 & 116 & 45 & 96 & 83 \\
\hline 32 & 114 & 55 & 98 & 86 \\
\hline 33 & 114 & 65 & 97 & 85 \\
\hline 34 & 112 & 60 & 104 & 93 \\
\hline 35 & 111 & 60 & 99 & 89 \\
\hline 36 & 105 & 75 & 97 & 92 \\
\hline 37 & 110 & 75 & 100 & 91 \\
\hline 38 & 106 & 90 & 106 & 100 \\
\hline 39 & 111 & 90 & 111 & 100 \\
\hline 40 & 106 & 105 & 106 & 100 \\
\hline 41 & 108 & 105 & 108 & 100 \\
\hline 42 & 100 & 120 & 100 & 100 \\
\hline 43 & 109 & 120 & 109 & 100 \\
\hline
\end{tabular}

distinct influence, if any, upon the rate of filling of the small intestine. Table 2 shows the results of these experiments. One sees that the advance of the food is most rapid during the first 5 minutes and after this lessens considerably. It is noteworthy that the terminal ileum was not less filled than the other parts of the small intestine, but instead of the food contained a yellowish slimy liquid. Evidently the food forced down from the stomach forces the slimy liquid of the "empty" small intestine towards the caecum, the iloecaecal valve still being closed. Thus the small intestine becomes filled in about 5 minutes, the advance of food being thereafter obstructed untill transport to the caecum begins.

The above results prompted another series of experiments with longer intervals between the beginning of the meal and the killing of the animals. The diet was about the same as diet $\mathrm{I}$ in the previous experiments. The results are seen in table 3 Only rats 40,42 , and 43 have any of the experimental food in the caecum. From these last experiments one may conclude that the transport of food through the ileocaecal valve does not commence until about $1 \frac{1}{2}$ hours after the beginning of the meal.

$$
\text { Summary and conclusions }
$$

Several series of experiments were arranged so as to study in the rat 1) the effect of the degree of the charge of the stomach upon its rate of emptying, and 2) the rate 
of passage of the food in the empty small intestine. It was observed that the fullness of the stomach had a positive influence on its rate of emptying. In the empty small intestine the transport of the food after the commencement of the meal is very rapid during the first 5 minutes. In this time the food is carried a distance from the pylorus comprising $53-65 \%$ of the length of the small intestine. Five minutes later $65-$ $78 \%$ of the small intestine contains experimental food. However, the terminal ileum does not appear to be less filled than the other parts of the small intestine. It contains a slimy liquid which has been forced from the mempty" small intestine towards the caecum. Evidently the ileocaecal valve has remained closed. Only after about $1 \frac{1}{2}$ hours does the food reach the distal end of the small intestine. It is obvious that the rapid filling of the duodenum and jejunum immediately after the beginning of the meal cannot be explained by the classical conception of peristalsis described by Bayliss and Starling. It is remarkable that in the rat the transport of food in the empty small intestine seems to occur at about the same relative rate as in man.

REF E R E N C S

(1) Barclay, A. E. 1936. The Digestive Tract, A Radiological Study of its Anatomy, Physiology, and Pathology. Cambridge.

(2) Ellenberger und Hofmeister, 1890. Die Verdauung von Fleisch bei Schweinen. Archivfür Physiologie.

(3) Evans, L. C. 1947. Principles of human physiology. London.

(4) Goodman, R. D., Lewis, A. E., Schukc, E. A. and Greenfield, M. A. 1952. Gastrointestinal Transit. The American Journal of Physiology, 169 (1).

(5) Krzywanek, Fr. W. 1926. Vergleichende Untersuchungen über die Mechanik der Verdauung. I. Mitteilung. Einleitung. Untersuchungen am Hund. Pflügers Archiv für die gesamte Physiologie des Menschen und der Tiere, 215.

(6) Lönnerblad, L. 1951. Transit time through the small intestine. Acta Radiologica. Supplementum 88.

(7) Magnus, R. 1908. Die stoppende Wirkung des Morphins. Pflügers Archiv für die gesamte Physiologie, 122 .

(8) Neimeier, K. 1939. Röntgenologische Beobachtungen am Magen-Darmkanal des Schweines. Inaugural-Dissertation. Hannover.

(9) Paloheimo, L. 1939. Über die Verwendung des quantitativen Indikatorverfahrens bei Untersuchung der Nahrungsfortbewegung im Magendarmkanal. Tierernährung II.

(10) Rieder, H. 1925. Die physiologische Dünndarm — Bewegung beim Menschen. Fortschritte auf dem Gebiete der Röntgenstrahlen, 33.

(11) Scheunert, A. und Trautmann, A. 1951. Lehrbuch der Veterinär-Physiologie. Berlin.

(12) Schinz, H. R., Baensch, W. E., Friedl, E., Uehlinger, E. 1952. Lehrbuch der Röntgendiagnostik. 7. Lieferung. Stuttgart.

(13) Stickney, J. C., van Liere, E. J., and Northup, D. W. 1951. Correlation Between Propulsive Motility and Length of the Small Intestine in Albino Rats and Dogs. The American Journal of Physiology, 167 (2).

(14) Swiney, B. A. and Spurrell, W. R. 1935. The Effect of Fat on Gastric Motility. The Journal of Physiology, 84. 
SELOST U S :

ERÄITÄ HAVAINTOJA RUOAN KULUSTA ROTAN RUOANSULATUSKANAVASSA

\author{
Lauri Paloheimo, Aarne Mäkelä ja Maija-Liisa Salo
}

Kotieläintieteellinen laitos, Helsingin Yliopisto

Kirjoittajat ovat etsineet selvitystä seuraavaan kahteen kysymykseen: 1) mahalaukun kuormitusasteen vaikutus sen tyhjentymisnopeuteen ja 2) ravinnon kulkunopeus tyhjässä ohutsuolessa. Edellisen kysymyksen tutkimiseen käytettiin 33 ja jälkimmäisen 43 rottaa. Todettiin, että mahalaukun täyteisyydellä oli positiivinen vaikutus sen tyhjenemisnopeuteen. Ruoansulatuskanavan ollessa tyhjän umpisuolta myöten, siirtyy osa mahalaukkuun tulleesta ruoasta välittömästi ohutsuoleen ja etenee siellä tavattoman nopeasti. Viidessä minuuttissa aterian alkamisesta laskien etenee ruoka $53-65 \%$ ohutsuolen pituudesta. Kuitenkin kestää n. 1 1 1/2 tuntia ennenkuin ruoka ehtii ohutsuolen loppupäähän. Osoittautui, että ruoan edettyä n. $75 \%$ ohutsuolen pituudesta myös ohutsuolen loppupää oli täysinäinen, sisältäen ruoan edellä sinne työntynyttä limaista nestettä, joka umpisuoleen johtavan aukon pysyessä suljettuna ei vielä voinut tulla tyhjennetyksi umpisuoleen. BAYLissin ja Starlingin klassillinen käsitys suolen peristaltiikasta ei riitä selittämään näissä kokeissa todettua ruoan nopeata etenemistä tyhjässä ohutsuolessa. 